\title{
Cholangitis: Diagnosis, Treatment and Prognosis
}

\author{
Amir Houshang Mohammad Alizadeh* \\ Taleghani Hospital, Shahid Beheshti University of Medical Sciences, Tehran, Iran
}

\begin{abstract}
Cholangitis is a serious life-threatening situation affecting the hepatobiliary system. This review provides an update regarding the clinical and pathological features of various forms of cholangitis. A comprehensive search was performed in the PubMed, Scopus, and Web of Knowledge databases. It was found that the etiology and pathogenesis of cholangitis are heterogeneous. Cholangitis can be categorized as primary sclerosing (PSC), secondary (acute) cholangitis, and a recently characterized form, known as IgG4-associated cholangitis (IAC). Roles of genetic and acquired factors have been noted in development of various forms of cholangitis. PSC commonly follows a chronic and progressive course that may terminate in hepatobiliary neoplasms. In particular, PSC commonly has been associated with inflammatory bowel disease. Bacterial infections are known as the most common cause for AC. On the other hand, IAC has been commonly encountered along with pancreatitis. Imaging evaluation of the hepatobiliary system has emerged as a crucial tool in the management of cholangitis. Endoscopic retrograde cholangiography, magnetic resonance cholangiopancreatography and endoscopic ultrasonography comprise three of the modalities that are frequently exploited as both diagnostic and therapeutic tools. Biliary drainage procedures using these methods is necessary for controlling the progression of cholangitis. Promising results have been reported for the role of antibiotic treatment in management of AC and PSC; however, immunosuppressive drugs have also rendered clinical responses in IAC. With respect to the high rate of complications, surgical interventions in patients with cholangitis are generally restricted to those patients in whom other therapeutic approaches have failed.
\end{abstract}

Citation of this article: Mohammad Alizadeh $\mathrm{AH}$. Cholangitis: diagnosis, treatment and prognosis. J Clin Transl Hepatol 2017;5(4):404-413. doi: 10.14218/JCTH.2017.00028.

Keywords: Primary sclerosing cholangitis; Acute cholangitis; IgG4-associated cholangitis; Endoscopic retrograde cholangiography; Magnetic resonance cholangiopancreatography; Endoscopic ultrasonography.

Abbreviations: $A C$, acute cholangitis; $A L P$, alkaline phosphatase; $A L T$, alanine aminotransferase; CBD, common bile duct; CIP, chronically ill patients; ERCP, endoscopic retrograde cholangiography; EUS, endoscopic ultrasonography; EUS-BD, EUS-guided biliary drainage; EUS-CDS, EUS-guided choledo-choduodenostomy; EUS-GBD, EUS-guided gallbladder drainage; EUS-HGS, EUS-guided hepaticogastrostomy; IAC, IgG4-associated cholangitis; IBD, inflammatory bowel disease; IDUS, intraductal ultrasonography; $M D R$, multidrug resistance; $M R C P$, magnetic resonance cholangiopancreatography; PSC, primary sclerosing cholangitis; PTBD, percutaneous transhepatic biliary drainage; SC-AIP, cholangitis-associated autoimmune pancreatitis; UC, ulcerative colitis.

Received: 28 April 2017; Revised: 23 June 2017; Accepted: 12 July 2017

*Correspondence to: Amir Houshang Mohammad Alizadeh, Taleghani Hospital, Shahid Beheshti University of Medical Sciences, Parvaneh Ave, Tabnak Str, Evin, Tehran 19857, Iran. Tel: +98-21-22432521, Fax: +98-21-22432517, E-mail: ahmaliver@yahoo.com

\section{Definition of cholangitis}

Cholangitis syndromes are complex end-stage hepatobiliary disorders. ${ }^{1}$ Given this broad concept, a wide range of abnormalities fall into the diagnostic criteria for cholangitis. These are generally associated with severe inflammation and fibrosis of the hepatobiliary system that is characterized by eventual narrowing and obstruction of the bile ducts. ${ }^{2}$ Therapeutic interventions for obviating the obstructive lesions in biliaryhepatic ducts is the primary approach for management of cholangitis. Nevertheless, the only established curative therapy for cholangitis is liver transplantation, especially in patients with progressed disease. ${ }^{3}$ New hopes are emerging, however, as improvements have been reported with therapies involving antibiotics and antifibrotic drugs.

\section{Various type of cholangitis}

The etiology and pathogenesis of various forms of cholangitis are heterogeneous. Cholangitis may be triggered by both genetic and acquired mediators. ${ }^{4}$ Cholangitis may also present as a primary immune condition. ${ }^{5}$ In a broad classification system, cholangitis cases can be divided into three main categories, including primary sclerosing cholangitis (PSC), secondary cholangitis, and immune cholangitis. ${ }^{6}$

PSC is a serious disorder with yet unknown etiology; however, a role has been proposed for immune dysregulation in the progression of PSC. ${ }^{4}$ Bacterial infections secondary to bile fluid stasis may also complicate PSC. ${ }^{7}$ On the other hand, the most common form of secondary cholangitis is acute cholangitis (AC; also known as recurrent pyogenic cholangitis, supportive cholangitis and ascending cholangitis). AC is characterized by infections involving the biliary system and leading to inflammation and obstruction of the biliary ducts. 8,9 Furthermore, the insidious role of the immune system has been highlighted in IgG4-associated cholangitis (IAC). Autoantibodies of IgA class that are reactive against biliary epithelial cell have been recently identified in IAC. ${ }^{10}$ Nevertheless, the immune system may not be the sole contributor in IAC, as bile stones or bile duct abnormalities also have been related to occurrence of this condition. ${ }^{11}$

\section{PSC}

PSC is a heterogeneous disease regarding histopathological features, clinical presentation and treatment response, as well as malignant transformation rate. ${ }^{12}$ PSC commonly follows a chronic and progressive course that may terminate in hepatobiliary neoplasms. ${ }^{13}$ PSC has shown higher rates of incidence in recent years, with reports of $1 / 10000$ in the population of Northern Europe. ${ }^{14,15}$ The majority of PSC-affected 
patients are men of European origin. ${ }^{15,16}$ However, PSC affects all age groups worldwide, with higher prevalence in the $3^{\text {rd }}$ and $7^{\text {th }}$ decades of life. ${ }^{17}$ Despite the suspected autoimmune nature of PSC, this condition is not responsive to immunosuppressive therapies. ${ }^{18}$

It has been noted that $90 \%$ of PSC cases are related to acquired environmental factors. ${ }^{13}$ PSC is commonly associated with inflammatory bowel disease (IBD). ${ }^{19}$ In fact, IBD-PSC has been proposed as a distinct clinical entity from isolated PSC, suggesting a strong association between the two disorders. ${ }^{20} \mathrm{~A}$ range of $34-75 \%$ of the patients with PSC suffer from IBD, with the majority presenting with ulcerative colitis (UC). ${ }^{2,21,22}$ There has been reported that this association highlights the role of gut microorganisms in PSC-IBS syndrome. ${ }^{23}$ Reduced number of T-regulatory cells in inflamed hepato-biliary tissues of patients with PSC suggests a role for immune hyperactivity in pathogenesis of this condition. ${ }^{24}$ In line with this, PSC may also develop in the context of other immune-mediated conditions, such as immune hepatitis, type 1 diabetes, sarcoidosis and immune thyroiditis. ${ }^{25}$

The role of demographic features in PSC remains controversial. In a cohort study by Fraga et al. ${ }^{26}$ demographic parameters including male sex, pancolitis, non-smoking and previous appendectomy were significant risk factors for PSC. Smoking seems to be a protective factor against cholangitis. ${ }^{20}$ The role of genetic predisposition in PSC has been noted. To date, 23 identified genetic loci have been related to PSC susceptibility. ${ }^{13}$ The DRB01*03 haplotype of human leukocyte antigen loci is one of the loci with strong relation to PSC development. ${ }^{16}$

\section{IAC}

Cholangitis presentation may be observed in the context of a broader autoimmune disorder characterized with high levels of IgG4 in serum along with proliferation of lymphocytic populations positive for IgG4 (known as IgG4-related cholangitis). ${ }^{11,27}$ Accordingly, IAC is characterized with infiltration of the biliary system with IgG4-positive lymphocytes. ${ }^{28}$ Involvement of the bile ducts and pancreatitis are common features described in AIC. IAC is predominantly encountered in older individuals, and is mainly a feature of male subjects. ${ }^{27,29,30}$ However, IAC has also been reported in children and adolescents ${ }^{31}$ the pathogenesis of this form of cholangitis is under investigation.

\section{IAC or PSC, a diagnostic dilemma}

With respect to the similar clinical features of IAC and PSC, the two may be misdiagnosed for one another. ${ }^{22}$ However, these two entities can be differentiated based on the dominance of IgM and albumin serum level in PSC, while elevated levels of IgG4 are a feature of IAC. ${ }^{22}$ The ratio of IgG4/IgG1 has also been suggested as useful for differentiating IAC from PSC. ${ }^{32}$ IAC may also be distinguished from PSC according to the context of its specific histological features, such as more pronounced infiltration by immune cells (plasma cells, lymphocytes, and eosinophils). ${ }^{30}$ The infiltrating plasma cells have been shown to express IgG4 in IAC. ${ }^{33}$ Eosinophilic infiltration of hepatic tissue in IAC may also be useful for differentiation of the two conditions. ${ }^{34}$

Association of IAC with pancreatitis is a useful parameter that could be exploited for discriminating IAC from PSC. ${ }^{27,30}$
In cases of isolated IAC without autoimmune pancreatitis, some features of IAC, including stenosis on cholangiography, stromal inflammation and response to immunosuppressive drugs, may be helpful in differential diagnosis. ${ }^{27}$ On the other hand, PSC patients show hepatic fibrous change, and segmental stricture as pathological findings. ${ }^{33}$ Presentation of obstructive jaundice, which is rarely seen in PSC, can assist in clinical differentiation of these two entities. ${ }^{35}$ In addition to these, one can bring into mind that patients with PSC are generally younger that those with IAC. ${ }^{33}$

\section{AC}

AC (as well as suppurative cholangitis or ascending cholangitis) was first identified as a disorder associated with recurrent fever, abdominal pain and jaundice. This clinical combination has been traditionally known as Charcot's triad. AC is primarily an infectious disease characterized by the proliferation of bacteria within bile and with the secondary blockage of biliary tracts. ${ }^{8}$ The Reynolds' pentad is defined as the occurrence of confusion and shock along with Charcot's triad. ${ }^{36}$

The initial version of the Tokyo Guidelines for the Management of AC and Cholecystitis (TG07) was introduced for the first time as a standard for diagnosis and management of $A C$; however, the TG07 suffered from lack of specificity and sensitivity, as well as having limited application in clinical practice. ${ }^{37,38}$ These flaws were obviated to a large extent by the revised guidelines that were published in 2013 (version TG13). The TG13 statements achieved both high sensitivity and specificity ( $87.6 \%$ and $77.7 \%$ respectively). This approach uses three domains, including clinical, laboratory and imaging findings, with 2, 4 and 1 items (Table 1). ${ }^{38}$ A severity score was also incorporated into the TG13. Based on this, AC can be classified into the following three grades: Grade III, severe form associated with organ failure; Grade II, moderate form requiring biliary drainage therapy; and Grade I, mild form including otherwise. ${ }^{37,39}$

Bile stone and obstruction of the bile duct are considered the main causes for acute bacterial cholangitis. ${ }^{36}$ In addition, bile duct obstruction in AC may also be triggered by other

Table 1. Diagnostic criteria for acute cholangitis, Tokyo Guidelines

\begin{tabular}{ll}
\hline Parameter & Items \\
\hline $\begin{array}{l}\text { Clinical } \\
\text { features }\end{array}$ & $\begin{array}{l}\text { 1. Previous biliary disorder } \\
\text { 2. Fever and/or chills } \\
\text { 3. Jaundice } \\
\text { 4. Abdominal pain }\end{array}$ \\
$\begin{array}{l}\text { Laboratory } \\
\text { features }\end{array}$ & $\begin{array}{l}\text { 5. Presence of inflammation indicators } \\
\text { C-reactive protein) }\end{array}$ \\
$\begin{array}{l}\text { Imaging } \\
\text { findings }\end{array}$ & $\begin{array}{l}\text { 7. Blevated liver enzymes } \\
\text { suggesting hepatobiliary disorder } \\
\text { diagnosis }\end{array}$ \\
$\begin{array}{l}\text { Two or more items of clinical features } \\
\text { diagnosis }\end{array}$ & $\begin{array}{l}\text { Either Charcot's triad (2+3+4) or two } \\
\text { items in the clinical features along with } \\
\text { both items in the laboratory and imaging } \\
\text { findings }\end{array}$ \\
\hline
\end{tabular}


etiologies. Choledocholithiasis has been described among the most common etiologies for AC; nevertheless, this phenomenon is often accompanied by secondary bacterial infections within the biliary system. ${ }^{40}$ Other etiologies include gallstones, malignancies (source being pancreas, gallbladder, cholangiocarcinoma, or metastatic tumors) or benign obstructions (surgical, pancreatitis, or chronic cholangitis), and some parasitic disorders. ${ }^{8}$ In a survey of 31 patients, Gossard et al. ${ }^{41}$ reported cholecystectomy, stones in bile ducts, chronic pancreatitis, and abdominal trauma as the causes for AC.

\section{Diagnostic modalities for cholangitis}

Imaging evaluation of the hepatobiliary system has the primary role in diagnostic modalities for cholangitis. Imaging evaluation also has applications in staging and management of cholangitis. ${ }^{42} \mathrm{~A}$ diagnostic imaging procedure for various forms of cholangitis should be able to reveal multiple characteristics of the biliary hepatic system, including stenosis and dilatation of bile ducts, as well as thickness of bile ducts walls, intrahepatic calculus, abnormalities of hepatic parenchymal tissue, evidences of hepatic dysplasia, and portal hypertension. ${ }^{6,43}$ The most frequently used imaging studies are endoscopic retrograde cholangiography (ERCP), magnetic resonance cholangiopancreatography (MRCP), and endoscopic ultrasonography (EUS). ${ }^{44}$

\section{Role of ERCP in cholangitis}

ERCP is the gold standard for diagnosis of cholangitis. ${ }^{45,46}$ ERCP may also be applied as a reference method for evaluating other imaging procedures, such as MRCP. ${ }^{47}$ ERCP can be effectively exploited for diagnosis of cholangiocarcinoma in PSC, with specificity and sensitivity of $97 \%$ and $65 \%$, respectively. ${ }^{48}$ Furthermore, ERCP delivers a high $(98.8 \%)$ success rate. Asymmetrical dilatation of bile ducts, as well as presence of calculi, is seen in ERCP. Decreased divisions of the biliary tree may be seen in ERCP with a more detailed resolution, thereby allowing for small ducts to be visualized. ${ }^{49}$ By the use of ERCP, complete assessment of a ductal tree may be accomplished, showing the presence of obstructive lesions and stenosis. ${ }^{50}$

Instead of a diagnostic method, ERCP may also be performed as a therapeutic procedure for biliary drainage in cholangitis. ${ }^{51}$ The role of biliary drainage procedures is of critical importance in the management of cholangitis. This approach provides a therapeutic alternative for patients who may not tolerate surgical drainage interventions. ${ }^{51}$ ERCPguided implantation of a biliary endoprosthesis or stent represents the gold standard therapeutic for biliary stricture. ${ }^{52}$ This method is an effective therapeutic modality that can be tolerated even by elderly patients. ${ }^{51}$ Therapeutic ERCP may be indicated when patients are in shock, show signs of nervous system involvement, or show coagulation defects. ${ }^{51}$ Overall, other drainage procedures may be considered in cases in which ERCP is not possible, or under conditions for which ERCP is not available. Performing ERCP may not be feasible when there is pyloric or duodenal stenosis. ERCP may also fail if the catheter cannot be inserted properly or in patients with prior operations on the gastrointestinal tract. ${ }^{52}$

It is suggested that the biliary drainage procedure be performed with 24 hours of the cholangitis diagnosis. ${ }^{53}$ Delay in performance of ERCP has been shown to increase the rate of recurrent cholangitis by $37 \% .{ }^{54}$ In accordance, ERCP is recommended to be performed within 24 hours of admission for patients with $A C$, as delaying this procedure can prolong hospital stay for these patients. ${ }^{55}$ Nevertheless, no significant differences were reported in mortality rate or hospital stay among patients with cholangitis who had undergone ERCP during 24, 48 or 72 hours after admission for the procedure. ${ }^{56}$ Timing of ERCP can be influenced by some factors, such as resuscitation period and hemostatic disease. ${ }^{55}$

ERCP is associated with higher rates of complications respective to other endoscopic procedures. These complications include pancreatitis, bleeding, trauma, and cardiopulmonary problems. ${ }^{57}$ ERCP may lead to complications such as pancreatitis in $1.2-4 \%$ and cholangitis in $2-2.5 \%$ of cases. ${ }^{58,59}$ Pancreatitis, perforation and bleeding, as well as cholangitis comprise the most common complications of ERCP in PSC patients. The overall rate of ERCP complications requiring hospital stay in PSC patients has been reported as $10 \% .{ }^{60}$ Other ERCP-related complications include increased common bile duct (CBD) diameter, biliary dilatation, biliary stent insertion, and cholangiocarcinoma. ${ }^{61}$

\section{MRCP}

$M R C P$, along with ERCP, is known to be one the most reliable procedures for diagnosing PSC. One major advantage of $M R C P$, however, is its noninvasive nature. In MRCP imaging, degree of intra- and extrahepatic bile duct, as well as gallstones and cholesterol stones, can be evaluated. In addition, low-diameter strictures are detectable by MRCP. ${ }^{62}$ MCRP provides $80 \%$ and $90 \%$ sensitivity and specificity for diagnosis of PSC, respectively. ${ }^{42}$ Considering the invasive nature of ERCP and its related complications, MRCP is gaining more and more pros as the first line assessment procedure in suspected PSC. ${ }^{63}$ MRCP is also an effective method to follow up the patients, and for screening to provide timely diagnosis of complications. ${ }^{63}$

In comparison to clinical based-diagnostic approaches, use of MRCP resulted in a 3-fold increase in identification of PSC patients. ${ }^{64}$ PSC can be characterized by randomly distributed annular strictures alternating with slightly dilated bile ducts, usually on both intra- and extrahepatic bile ducts in MRCP analysis. ${ }^{63,65}$ MRCP has the ability to accurately detect stones of large size in the CBD. ${ }^{44}$ Nevertheless, sensitivity of MRCP in identifying small stones is not satisfactory. ${ }^{44}$ In addition; MRCP may miss bile duct dilatations in PSC. ${ }^{66}$

\section{Role of EUS in cholangitis}

Sonography is a relatively inexpensive and widely available method of imaging. EUS eventually may replace ERCP as a primary procedure for biliary drainage. ${ }^{67}$ Endoscopic procedures are important in many aspects for managing patients with cholangitis, encompassing diagnostic, therapeutic and monitoring of the disease. Biliary duct dilatation, and small stones can be well diagnosed by EUS. ${ }^{44}$ For detection of malignant transformations, EUS is a useful method and superior to ERCP. ${ }^{68}$

Regarding the invasiveness of ERCP and the low sensitivity of MRCP to detect cholangitis lesions in early stages of the disease, EUS has been proposed as a useful first-line diagnostic tool for cases with suspected cholangitis. ${ }^{69}$ With respect to ERCP, EUS has the benefit of lower complication rates; and with respect to $\mathrm{MRCP}$, it has significantly lower 
costs. ${ }^{70}$ EUS may become the first-line therapeutic and diagnostic method for biliary hepatic disorders in the near future.

EUS is also considered as an alternative drainage method for cases in which ERCP has failed. ${ }^{67,71}$ The therapeutic approach of EUS in biliary hepatic diseases, designated as EUS-guided biliary drainage (EUS-BD), has been introduced as an alternative option for other drainage methods, such as percutaneous transhepatic biliary drainage (PTBD) and ERCP (Table 2). The endoscopic drainage encompasses balloondilatation and/or stenting of strictures, and improves the clinical picture and biliary-liver enzyme profile. ${ }^{72}$

EUS-BD is divided into EUS-guided choledo-choduodenostomy (EUS-CDS), EUS-guided hepaticogastrostomy (EUS-HGS) and EUS-guided gallbladder drainage (EUS-GBD) that can be used in various obstructive biliary hepatic disorders, each with a high rate of success $\left(93 \%, 97 \%\right.$ and $100 \%$, respectively). ${ }^{73}$ Nevertheless, regarding the low rate of complications of EUS, there has been suggestion to consider the EUS-BD as the first line therapy, even in cases without failed ERCP. ${ }^{67,74}$ Another advantage of the EUS-BD approach is preserving bile flow, as compared to PTBD or surgical drainage methods. ${ }^{75}$ However, stent occlusion, migration and shortening are among the difficulties faced by EUS-BD, all of which may necessitate stent replacement. $^{76}$

Radial EUS has been applied for diagnostic goals in AC. Concentric wall thickness of bile ducts has been noted as the most reliable finding to predict correct diagnosis of AC by this method. ${ }^{77}$ Intraductal ultrasonography (IDUS) diagnostic modalities have been noted to be useful in differentiation of PSC and IAC. Irregular inner margin, diverticulum-like outpouching and obliteration of three layers are the IDUS features specific for PSC, in comparison with IAC. ${ }^{78}$ IDUS analysis in IAC patients shows circular-symmetric wall thickness, smooth outer margin, smooth inner margin and homogeneous internal echo in the stricture. A bile duct wall thickness greater than $0.8 \mathrm{~mm}$ in regions of non-stricture on the cholangiogram is a feature specific to IAC. ${ }^{79}$
Transabdominal US has been successfully applied for diagnosis of IAC, by observing thickness of the bile duct walls. ${ }^{80}$ In this regard, results of IDUS can be used for characterization and identification of cholangitis-associated autoimmune pancreatitis (SC-AIP) from PSC or biliary caner, which is characterized with symmetrical wall thickness, presence of homogeneous internal foci and presence of lateral mucosal lesions continuous to the hilar. ${ }^{81}$

IDUS findings could also be used for estimating severity of cholangitis, namely by irregular inner surface, heterogeneous internal echo, and irregular outer contour, which correlate with severity of cholangitis. ${ }^{82}$

\section{Antibiotics for cholangitis}

New light has been shedding on the role of microbial components in development of various forms of cholangitis. Due to the high rate of positive microbial cultures from the bile ducts of cholangitis patients, it has been suggested to obtain a microbial profile before performing drainage methods. The most common bacterial infections in cholangitis include the Escherichia coli, Klebsiella spp., pesudomonal species, Enterobacter spp., Acinetobacter spp. of Gram-negative bacteria, and enterococcus, streptococcus, and staphylococcus Grampositive bacteria. ${ }^{84,85}$ Selection of antibiotics may be influenced by multiple factors, such as prior exposure of patients with hospital-acquired infections, as well as the severity of the disease. ${ }^{44}$ For the best practice, administrated antibiotics for cholangitis should be those with broad range antimicrobial activities and which are capable of passing into the bile duct, such as third-generation cephalosporins, ureidopenicillins, carbapenems and fluoroquinolones. ${ }^{86}$ The most effective antibiotics for cholangitis patients have been noted as imipenem-cilastatin, meropenem, amikacin, cefepime, ceftriaxone, gentamicin, piperacillin-tazobactam and levofloxacin. ${ }^{87,88}$

Table 2. Applications of endoscopic ultrasonography in cholangitis

\begin{tabular}{|c|c|c|c|c|}
\hline $\begin{array}{l}\text { Type of } \\
\text { cholangitis }\end{array}$ & EUS approach & $\begin{array}{l}\text { Number } \\
\text { of patients }\end{array}$ & Specific diagnostic findings & $\begin{array}{l}\text { Reference, } \\
\text { year }\end{array}$ \\
\hline IAC & $\begin{array}{l}\text { Transabdominal } \\
\text { ultrasonography }\end{array}$ & 2 & Bile duct thickening & $\begin{array}{l}\text { Kobori et al. }{ }^{80} \\
2016\end{array}$ \\
\hline PSC and IAC & IDUS & $\begin{array}{l}15 \text { patients with PSC } \\
\text { and } 35 \text { patients } \\
\text { with IAC }\end{array}$ & $\begin{array}{l}\text { Irregular inner margin, diverticulum-like } \\
\text { outpouching, disappearance of three } \\
\text { layers are specific for PSC }\end{array}$ & $\begin{array}{l}\text { Naitoh et al., } \\
2015\end{array}$ \\
\hline AC & Radial EUS & 28 & $\begin{array}{l}\text { Diffuse and/or concentric wall thickening } \\
\text { (more than } 1.5 \mathrm{~mm} \text { ), and intraductal } \\
\text { heterogeneous echogenicity without } \\
\text { acoustic shadowing are suggestive for AC }\end{array}$ & $\begin{array}{l}\text { Alper et al., } \\
2011\end{array}$ \\
\hline IAC & $\begin{array}{l}\text { Transpapillary } \\
\text { IDUS }\end{array}$ & 23 & $\begin{array}{l}\text { Bile duct wall thickness more than } 0.8 \mathrm{~mm} \\
\text { in regions of non-stricture is highly } \\
\text { suggestive of IAC }\end{array}$ & $\begin{array}{l}\text { Naitoh et al., } \\
2009\end{array}$ \\
\hline $\begin{array}{l}\text { AIDS- } \\
\text { related } \\
\text { sclerosing } \\
\text { cholangitis }\end{array}$ & Simple & 50 & $\begin{array}{l}\text { EUS findings are highly correlated with } \\
\text { ERCP findings }\end{array}$ & $\begin{array}{l}\text { Daly et al.., } \\
1996\end{array}$ \\
\hline
\end{tabular}

Abbreviations: AC; acute cholangitis; AIDS, autoimmune deficiency syndrome; EUS, endoscopic ultrasonography; ERCP, endoscopic retrograde cholangiography; IAC, IgG4associated cholangitis; IDUS, intraductal ultrasonography; PSC, primary sclerosing cholangitis. 


\section{Antibiotics in AC}

The rates of polymicrobial-positive cultures in $\mathrm{AC}$ vary from $30-78 \%, 86,89,90$ and the response rate to antibiotics in $A C$ is satisfactory in the majority of patients. ${ }^{40}$ The achievement of effective antibiotic therapy for AC decreased the death rate of this condition dramatically during the 1970 s through $1980 .{ }^{40}$

An appropriate profile of antibiotic administration is vital in the early stages of acute infectious cholangitis. The majority of patients with acute bacterial cholangitis benefit from board-spectrum antibiotics. ${ }^{36}$ It is an immediate need to administrate antibiotic therapy along with procedures performed for correcting the biliary obstruction. ${ }^{90}$ There are no recommendations for discontinuing of antibiotic therapy, however, and it seems that cessation after relief from clinical symptoms, such as fever, and following drainage therapy has no adverse outcomes on the clinical course of the disease. ${ }^{53}$

In parallel, short-duration antibiotic therapy (of 3 days) appears sufficient when adequate drainage is achieved and fever is abating. ${ }^{91}$ Regardless, it is highly recommended to preserve antibiotic therapy in the early phases of $\mathrm{AC}{ }^{44} \mathrm{Fur}-$ thermore, as septic shock is a potential threat in $A C$, it is a necessity to administrate broad-spectrum antibiotic therapies as early as possible (within 1-4 hours) following signs of septic shock development. ${ }^{92}$ Either oral or intravenous administration of antibiotics seemed to be of equal efficiency in eradiation of bacteria in AC patients. ${ }^{93}$

Resistance to various antibiotics, including quinolone, carbapenems, vancomycin and ampicillin, has been observed in cultures isolated form AC patients. ${ }^{90}$ In a study of a German population, $29 \%$ multidrug resistant (MDR) isolates were recovered from bile cultures of patients with AC. Risk factors for MDR in that study included male sex, previous antibiotic therapy and biliary stenting, with the recent factor being an independent risk factor. ${ }^{90}$ Also, stent therapy was reported as a significant risk factor for acquiring MDR infections in AC patients. ${ }^{94}$

\section{Antibiotics in PSC}

The beneficial role of antibiotics in PSC is controversial. ${ }^{95}$ A high rate of positive cultures has been reported for PSC patients. ${ }^{86,89}$ The idea that antibiotic therapy may be useful in slowing down the progression of PSC originates from studies that described a role for bacterial species residing in the human gastrointestinal tract in the pathogenesis of PSC. ${ }^{96}$ However, antibiotic therapy for 12 weeks with rifaximin resulted in no significant effects on the clinical course of PSC. 97

In contrast, using vancomycin in conjunction with routine ursodeoxycholic acid therapy resulted in decreased liver enzyme levels in PSC patients, and in a relief of some clinical symptoms such as fatigue, pruritus, diarrhea and anorexia. ${ }^{98}$ Significant reduction of alkaline phosphatase (ALP) enzyme was also observed in PSC patients treated with a combination of ursodeoxycholic acid and metronidazole, in comparison with ursodeoxycholic acid and placebo. ${ }^{99}$ Vancomycin administration also improved alanine aminotransferase (ALT), gamma-glutamyl transpeptidase, and erythrocyte sedimentation rate in children with PSC. ${ }^{100}$

Both vancomycin and metronidazol therapy were found effective during a 3-month treatment period resulting in reduced ALT and bilirubin levels, and in the Mayo PSC risk score. ${ }^{101}$ Vancomycin administration in patients with PSC-IBD resulted in an elevation in T-regulatory CD4+, CD25+ lymphocytes, which can modulate immune system activity. This was further reported to be associated with normalization of ALT and leukocyte counts in PSC. ${ }^{43}$

\section{Role of surgery in cholangitis}

Surgical intervention in cholangitis provides either a selective or emergency option. Although invasive, surgical intervention generally results in more persistent regression of the cholangitis. ${ }^{102}$ Choosing a surgical intervention is dependent upon multiple factors, including patient characteristics (fulfilling requirement for general anesthesia, tolerability of surgical procedure, history of treatment failure) and pathological features of the hepatobiliary lesions and obstructions (Table 3). ${ }^{103}$ Surgical therapy has been indicated for PSC patients with major obstructive lesions which failed removal by endoscopic drainage methods. ${ }^{104}$ Accordingly, the surgical approach has been described as an effective treatment in AC that can be associated with significant improvement of clinical symptoms with the least post-surgical complications (3-6\%). ${ }^{105}$ It's noteworthy that caution must be taken to avoid unnecessary surgical intervention for IAC cases who may be misdiagnosed as bile duct carcinoma. ${ }^{106,107}$

Liver transplantation is the definitive surgical treatment for PSC. ${ }^{108}$ Surgical treatment may also be indicated as a drainage procedure. ${ }^{103}$ In such cases, surgery is the method of choice when other drainage methods such as ERCP and EUS-BD are not possible. ${ }^{108}$ The drainage interventions along with surgery is indicated in cases with duct strictures, dilation or obstructive stones. Most commonly, hepaticojejunostomy is the method of choice for surgical biliary drainage. ${ }^{103}$ Patients who underwent surgical drainage showed a higher mortality rate and longer hospital stay than those treated with endoscopic drainage. ${ }^{111}$ Surgery may also be performed as partial hepatectomy in patients with cholangitis. ${ }^{112}$ Generally, liver resection approaches are considered in cases with tissue hypertrophy or in cases with suspected cancer. ${ }^{103}$ Interestingly, curative success of partial liver resection has been noted in three patents with PSC, but large cohort studies are needed for confirmation. ${ }^{112}$

\section{Outcome and prognosis of cholangitis}

Regardless of etiology, cholangitis is a serious life-threatening biliary-hepatic condition. A scoring system based on four parameters, including fever, hyper bilirubinemia, bile duct dilatation and presence of bile duct stones, has been proposed to predict severity of cholangitis. ${ }^{113}$

\section{Prognostic features of AC}

In a comparison between PSC and secondary SC patients, those with secondary diseases showed poorer prognosis and shorter life expectancy. ${ }^{41}$ Using a delta neutrophil index which reflects the number of circulating immature granulocytes in blood has been noted as a significant prognostic factor in AC. In this regard, higher index corresponded with higher rate of early mortality in AC patients. ${ }^{114}$

Severe obstructions of bile ducts can cause extreme infected bile reflux and appearance of bacteria in blood, rendering a dire situation. In addition, low level of serum albumin along with prothrombin time (international normalized ratio) of $>1.5$ were associated with poorer prognosis and 


\begin{tabular}{|c|c|c|c|c|}
\hline $\begin{array}{l}\text { Cholangitis } \\
\text { type }\end{array}$ & $\begin{array}{l}\text { Number of patients, } \\
\text { period and country of } \\
\text { origin, sex, median age }\end{array}$ & Surgical procedures & Complications & Ref \\
\hline $\begin{array}{l}\text { Recurrent } \\
\text { pyogenic } \\
\text { cholangitis }\end{array}$ & $\begin{array}{l}94,2007-2016 \\
\text { India, } 66 \text { women and } \\
28 \text { men, median age } \\
40 \text { years }\end{array}$ & $\begin{array}{l}\text { Drainage procedure }(\mathrm{HJ})(53 \%) \text {, } \\
\text { left hepatectomy }(19 \%) \text {, left lateral } \\
\text { segmentectomy }(14 \%) \text {, right } \\
\text { hepatectomy }(4 \%) \text {, right posterior } \\
\text { sectorectomy }(1 \%) \text {, left } \\
\text { hepatectomy }+\mathrm{HJ} 5 \% \text {, left lateral } \\
\text { segmentectomy }+\mathrm{HJ}(2 \%) \text {, Right } \\
\text { hepatectomy + } \\
\mathrm{HJ}(1 \%)\end{array}$ & $\begin{array}{l}\text { Surgery-related complications in } \\
32 / 94 \text { patents, mild wound infection } \\
\text { (9), severe wound infection (10), } \\
\text { postoperative bile leak (6), } \\
\text { postoperative hemorrhage requiring } \\
\text { blood transfusion ( } 1) \text {, chest infection } \\
\text { (2), acute cholangitis (2), acute renal } \\
\text { failure (1), sepsis (1) }\end{array}$ & 102 \\
\hline $\begin{array}{l}\text { Recurrent } \\
\text { pyogenic } \\
\text { cholangitis }\end{array}$ & $\begin{array}{l}80,2001-2010 \text { Hong } \\
\text { Kong, } 45 \text { women and } \\
35 \text { men, median age } \\
60 \text { years }\end{array}$ & $\begin{array}{l}\text { Hepaticocutaneousjejunostomy } \\
(100 \%) \text {, left lateral sectionectomy } \\
(19 / 80) \text {, left hepatectomy }(11 / 80) \text {, } \\
\text { right hepatectomy }(5 / 80), \text { right } \\
\text { posterior hepatectomy }(2 / 80) \text {, } \\
\text { segment VIII resection }(1 / 80)\end{array}$ & $\begin{array}{l}23 / 80 \text { ( } 28.8 \%) \text { residual stones, } \\
31.3 \% \text { recurrent stones, wound } \\
\text { infection }(9) \text {, postoperative ileus ( } 1) \text {, } \\
\text { intra-abdominal collection requiring } \\
\text { drainage (1), bile leak (1), incisional } \\
\text { hernia (2) }\end{array}$ & 109 \\
\hline $\begin{array}{l}\text { Recurrent } \\
\text { pyogenic } \\
\text { cholangitis }\end{array}$ & $\begin{array}{l}85,1995-2008 \\
\text { China, } 50 \text { women and } \\
35 \text { men, median age } \\
61 \text { years }\end{array}$ & $\begin{array}{l}\text { Hepatectomy }(65.9 \%) \text {, left } \\
\text { hepatectomy }(15.3 \%) \text {, left lateral } \\
\text { sectionectomy }(47.1 \%) \text {, right } \\
\text { hepatectomy }(2.4 \%) \text {, right posterior } \\
\text { sectionectomy }(1.2 \%) \text {, hepatectomy } \\
\text { + drainage procedure }(9.4 \%) \text {, left } \\
\text { hepatectomy + HJ }(2.4 \%) \text {, left lateral } \\
\text { sectionectomy + HJ }(4.7 \%) \text {, left } \\
\text { lateral sectionectomy + } \\
\text { sphincteroplasty }(1.2 \%) \text {, right } \\
\text { hepatectomy + HJ }(1.2 \%) \text {, drainage } \\
\text { procedure }(14.1 \%), \\
\text { hepaticojejunostomy }(7.1) \text {, } \\
\text { transduodenal sphincteroplasty } \\
(1.2 \%), \text { T-tube drainage (5.9\%), } \\
\text { percutaneous choledochoscopy } \\
(10.6 \%)\end{array}$ & $\begin{array}{l}\text { Wound infection ( } 50 \%) \text {, intra- } \\
\text { abdominal collection }(21.7 \%) \text {, } \\
\text { pleural effusion }(6.5 \%) \text {, bile leak } \\
(4.3 \%) \text {, atrial fibrillation }(4.3 \%) \text {, } \\
\text { wound dehiscence }(2.2 \%) \text {, incisional } \\
\text { hernia }(2.2 \%) \text {, others }(8.7 \%)\end{array}$ & 103 \\
\hline $\begin{array}{l}\text { Recurrent } \\
\text { pyogenic } \\
\text { cholangitis }\end{array}$ & $\begin{array}{l}27,1986-2005 \text { USA, } \\
15 \text { women and } 12 \\
\text { men, median age } \\
54.3 \text { years }\end{array}$ & $\begin{array}{l}\text { Liver resection+ } \\
\text { choledochojejunostomy with Hutson } \\
\text { access loop }(11 / 27) \text {, liver resection } \\
\text { only }(6 / 27) \text {, common bile duct } \\
\text { exploration }(10 / 27)\end{array}$ & $\begin{array}{l}\text { Wound infection ( } 3 \text { ), deep venous } \\
\text { thrombosis ( } 1) \text {, perihepatic } \\
\text { hematoma (1), perihepatic abscess } \\
\text { (3), hepatic insufficiency ( } 1 \text { ) }\end{array}$ & 110 \\
\hline
\end{tabular}

Abbreviation: $\mathrm{HJ}$, hepaticojejunostomy.

refractory disease in AC. ${ }^{115}$ In another study, the five adverse predictive factors of AC included hyperbilirubinemia, high fever, leukocytosis, advance age and hypoalbuminemia. ${ }^{36}$ Likewise, parameters such as higher age, low blood pressure, leukocytosis, high C-reactive protein, and long period of antibiotic therapy were associated with poor prognosis in AC. ${ }^{116}$ Likewise, severe leukocytosis $(>20.000 / \mu \mathrm{L})$ and total bilirubin $>10 \mathrm{mg} / \mathrm{dL}$ have been associated with adverse outcome in AC. ${ }^{117}$

\section{Prognostic features in PSC}

Generally, PSC is a progressive disorder associated with the least response to routine therapeutics. There is still no established drug with true known positive effect on PSC. Despite the proposed role for the immune system in the development of PSC, effectiveness of immunosuppressive drugs involves slowing down the progression of the disease, but the mechanism is not clear. Liver transplantation is currently the only established treatment. Antibiotic and antifibrotic agents have shown beneficial effects in $\mathrm{PSC}^{2}$ but the overall results are controversial.

Hepatic involvement in PSC is characterized by a progressive fibrotic condition. Eventual deterioration of the bile duct in PSC may ultimately result in liver cirrhosis. Furthermore, development of extra- and intrahepatic ducts may accelerate neoplastic transformation. ${ }^{16}$ The patients are at risk of cholangiocarcinoma, hepatic cancer, biliary cancer, and colon cancer. $^{2,4,118}$ The estimated rate of cholangiocarcinoma is as high as $10-12 \%$ in PSC patients. ${ }^{118,119}$ To this rate, one should incorporate a $2-4 \%$ risk of hepatocellular carcinoma in end-stage liver disease. ${ }^{118}$ The overall risk of neoplastic diseases in PSC is estimated to be $13-14 \% .{ }^{42}$ In another crude estimate, PSC patients are considered likely to die 
from cancer in $40-58 \%$ of cases. ${ }^{42}$ Overall, life expectancy of $>10$ years has reached $80 \%$ for PSC patients who undergo liver transplantation. ${ }^{42}$ Patients with PSC may survive 12-15 years following diagnosis of PSC if not treated with liver transplantation. ${ }^{2,23}$

The main determinants of prognosis of PSC patients are timely diagnosis, appropriate timing of liver transplantation, and well management of the complications. ${ }^{42}$ Other reported prognostic factors with poor outcome include higher ages, ${ }^{120,121}$ higher levels of serum bilirubin, ${ }^{120-122}$ albumin, alkaline phosphatase, presence of hepatomegaly, and/or splenomegaly. ${ }^{121,122}$ Complications of PSC with bacterial infection is a further adverse feature of PSC that can result in recurrent acute cholangitis. ${ }^{7}$ Risk of death, requirement of liver transplant, and malignancy were significantly higher in PSC patients with concurrent IBD. ${ }^{123}$ Lower age onset of PSC seems to be a better prognostic factor respective to adulthood disease; however, in one-third of pediatric cases, the disease may be progressive. ${ }^{21}$ Septic shock in PSC is a serious adverse outcome, with a high rate of mortality and a median survival rate of 1.1 years. ${ }^{124}$ ALP level has been suggested as a prognostic factor that is capable of predicting such outcomes as need for liver transplantation and PSC-associated death. ${ }^{125}$

\section{Prognostic factors in IAC}

Generally, IAC patients seem to have more favorable prognosis than PSC patients. ${ }^{22}$ IAC patients respond to steroid therapy, ${ }^{28}$ but involvement of several organs in IAC has been associated with adverse outcome and failure of steroid treatment in IAC. 126

\section{Conflict of interest}

The author has no conflict of interest related to this publication.

\section{Author contributions}

Conception and design, collection and assembly of data, data analysis and interpretation, manuscript writing, final approval of manuscript (AHMA).

\section{References}

[1] Lee SP, Roberts JR, Kuver R. The changing faces of cholangitis. F1000Res 2016;5:1409. doi: 10.12688/f1000research.8745.1.

[2] Yimam KK, Bowlus CL. Diagnosis and classification of primary sclerosing cholangitis. Autoimmun Rev 2014;13:445-450. doi: 10.1016/j.autrev. 2014.01.040

[3] Sinakos E, Lindor K. Treatment options for primary sclerosing cholangitis. Expert Rev Gastroenterol Hepatol 2010;4:473-488. doi: 10.1586/egh.10.33.

[4] Karlsen TH, Boberg KM. Update on primary sclerosing cholangitis. J Hepatol 2013;59:571-582. doi: 10.1016/j.jhep.2013.03.015.

[5] Girard M, Franchi-Abella S, Lacaille F, Debray D. Specificities of sclerosing cholangitis in childhood. Clin Res Hepatol Gastroenterol 2012;36:530-535. doi: 10.1016/j.clinre.2012.04.003.

[6] Arrivé L, Ruiz A, El Mouhadi S, Azizi L, Monnier-Cholley L, Menu Y. MRI of cholangitis: traps and tips. Diagn Interv Imaging 2013;94:757-770. doi: 10.1016/j.diii.2013.03.006

[7] Goldberg DS, Camp A, Martinez-Camacho A, Forman L, Fortune B, Reddy KR. Risk of waitlist mortality in patients with primary sclerosing cholangitis and bacterial cholangitis. Liver Transpl 2013;19:250-258. doi: 10.1002/It. 23587.

[8] Mosler P. Diagnosis and management of acute cholangitis. Curr Gastroenterol Rep 2011;13:166-172. doi: 10.1007/s11894-010-0171-7.
[9] Seo N, Kim SY, Lee SS, Byun JH, Kim JH, Kim HJ, et al. Sclerosing cholangitis: clinicopathologic features, imaging spectrum, and systemic approach to differential diagnosis. Korean J Radiol 2016;17:25-38. doi: $10.3348 / \mathrm{kjr}$. 2016.17.1.25.

[10] Berglin L, Björkström NK, Bergquist A. Primary sclerosing cholangitis is associated with autoreactive IgA antibodies against biliary epithelial cells. Scand J Gastroenterol 2013;48:719-728. doi: 10.3109/00365521.2013. 786131.

[11] Silveira MG. IgG4-associated cholangitis. Clin Liver Dis 2013;17:255-268. doi: 10.1016/j.cld.2012.11.007.

[12] Krones E, Graziadei I, Trauner M, Fickert P. Evolving concepts in primary sclerosing cholangitis. Liver Int 2012;32:352-369. doi: 10.1111/j.14783231.2011.02607.x.

[13] Chung BK, Hirschfield GM. Immunogenetics in primary sclerosing cholangitis. Curr Opin Gastroenterol 2017;33:93-98. doi: 10.1097/MOG. 0000000000000336.

[14] Takakura WR, Tabibian JH, Bowlus CL. The evolution of natural history of primary sclerosing cholangitis. Curr Opin Gastroenterol 2017;33:71-77. doi: 10.1097/MOG.0000000000000333.

[15] Kingham JG, Kochar N, Gravenor MB. Incidence, clinical patterns, and outcomes of primary sclerosing cholangitis in South Wales, United Kingdom. Gastroenterology 2004;126:1929-1930. doi: 10.1053/j.gastro.2004. 04.052.

[16] Aron $\mathrm{JH}$, Bowlus CL. The immunobiology of primary sclerosing cholangitis. Semin Immunopathol 2009;31:383-397. doi: 10.1007/s00281-009-0154-7.

[17] Takikawa H, Takamori Y, Tanaka A, Kurihara H, Nakanuma Y. Analysis of 388 cases of primary sclerosing cholangitis in Japan; Presence of a subgroup without pancreatic involvement in older patients. Hepatol Res 2004;29: 153-159. doi: 10.1016/j.hepres.2004.03.006.

[18] Mattner J. Impact of microbes on the pathogenesis of primary biliary cirrhosis (PBC) and primary sclerosing cholangitis (PSC). Int J Mol Sci 2016; 17:1864. doi: 10.3390/ijms17111864.

[19] Mieli-Vergani G, Vergani D. Sclerosing cholangitis in children and adolescents. Clin Liver Dis 2016;20:99-111. doi: 10.1016/j.cld.2015.08.008.

[20] Williamson KD, Chapman RW. Primary sclerosing cholangitis. Dig Dis 2014 32:438-445. doi: 10.1159/000358150.

[21] Tenca A, Färkkilä M, Arola J, Jaakkola T, Penagini R, Kolho KL. Clinical course and prognosis of pediatric-onset primary sclerosing cholangitis. United European Gastroenterol J 2016;4:562-569. doi: 10.1177/2050640615 616012.

[22] Tanaka A, Tazuma S, Okazaki K, Tsubouchi H, Inui K, Takikawa H. Nationwide survey for primary sclerosing cholangitis and IgG4-related sclerosing cholangitis in Japan. J Hepatobiliary Pancreat Sci 2014;21:43-50. doi: 10. $1002 / j h b p .50$

[23] Tabibian JH, O'Hara SP, Lindor KD. Primary sclerosing cholangitis and the microbiota: current knowledge and perspectives on etiopathogenesis and emerging therapies. Scand J Gastroenterol 2014;49:901-908. doi: 10. 3109/00365521.2014.913189.

[24] Schwinge D, von Haxthausen F, Quaas A, Carambia A, Otto B, Glaser F, et al. Dysfunction of hepatic regulatory $T$ cells in experimental sclerosing cholangitis is related to IL-12 signaling. J Hepatol 2017;66:798-805. doi: 10. 1016/j.jhep.2016.12.001.

[25] Lamberts LE, Janse M, Haagsma EB, van den Berg AP, Weersma RK. Immune-mediated diseases in primary sclerosing cholangitis. Dig Liver Dis 2011;43:802-806. doi: 10.1016/j.dld.2011.05.009.

[26] Fraga M, Fournier N, Safroneeva E, Pittet V, Godat S, Straumann A, et al. Primary sclerosing cholangitis in the Swiss Inflammatory Bowel Disease Cohort Study: prevalence, risk factors, and long-term follow-up. Eur ] Gastroenterol Hepatol 2017;29:91-97. doi: 10.1097/MEG.0000000000000747.

[27] Nakazawa T, Shimizu S, Naitoh I. IgG4-Related Sclerosing Cholangitis. Semin Liver Dis 2016;36:216-228. doi: 10.1055/s-0036-1584321.

[28] Li J, Zhao C, Shen Y. Autoimmune cholangitis and cholangiocarcinoma. J Gastroenterol Hepatol 2012;27:1783-1789. doi: 10.1111/j.1440-1746. 2012.07287.x.

[29] Beuers U, Maillette de Buy Wenniger LJ, Doorenspleet M, Hubers L, Verhei J, van Gulik T, et al. IgG4-associated cholangitis. Dig Dis 2014;32:605-608. doi: $10.1159 / 000360513$.

[30] Deshpande V, Sainani NI, Chung RT, Pratt DS, Mentha G, Rubbia-Brandt L, et al. IgG4-associated cholangitis: a comparative histological and immunophenotypic study with primary sclerosing cholangitis on liver biopsy material. Mod Pathol 2009;22:1287-1295. doi: 10.1038/modpathol.2009.94.

[31] Smolka V, Karaskova E, Tkachyk O, Aiglova K, Ehrmann J, Michalkova K, et al. Long-term follow-up of children and adolescents with primary sclerosing cholangitis and autoimmune sclerosing cholangitis. Hepatobiliary Pancreat Dis Int 2016;15:412-418. doi: 10.1016/S1499-3872(16)60088-7.

[32] Boonstra K, Culver EL, de Buy Wenniger LM, van Heerde MJ, van Erpecum $\mathrm{KJ}$, Poen $\mathrm{AC}$, et al. Serum immunoglobulin $\mathrm{G} 4$ and immunoglobulin $\mathrm{G} 1$ for distinguishing immunoglobulin G4-associated cholangitis from primary sclerosing cholangitis. Hepatology 2014;59:1954-1963. doi: 10.1002/hep. 26977. 
[33] Nishino $T$, Oyama $\mathrm{H}$, Hashimoto $\mathrm{E}$, Toki $\mathrm{F}$, Oi I, Kobayashi $\mathrm{M}$, et al. Clinicopathological differentiation between sclerosing cholangitis with autoimmune pancreatitis and primary sclerosing cholangitis. J Gastroenterol 2007;42:550-559. doi: 10.1007/s00535-007-2038-8.

[34] Walter D, Hartmann S, Herrmann E, Peveling-Oberhag J, Bechstein WO, Zeuzem S, et al. Eosinophilic cholangitis is a potentially underdiagnosed etiology in indeterminate biliary stricture. World J Gastroenterol 2017;23: 1044-1050. doi: 10.3748/wjg.v23.i6.1044.

[35] Novotný I, Dítě P, Trna J, Lata J, Husová L, Geryk E. Immunoglobulin G4-related cholangitis: a variant of IgG4-related systemic disease. Dig Dis 2012;30:216-219. doi: 10.1159/000336706.

[36] Zimmer V, Lammert F. Acute Bacterial Cholangitis. Viszeralmedizin 2015; 31:166-172. doi: 10.1159/000430965.

[37] Kiriyama S, Takada T, Strasberg SM, Solomkin JS, Mayumi T, Pitt HA, et al. TG13 guidelines for diagnosis and severity grading of acute cholangitis (with videos). J Hepatobiliary Pancreat Sci 2013;20:24-34. doi: 10.1007/ s00534-012-0561-3.

[38] Takada T, Kawarada Y, Nimura Y, Yoshida M, Mayumi T, Sekimoto M, et al. Background: Tokyo Guidelines for the management of acute cholangitis and cholecystitis. J Hepatobiliary Pancreat Surg 2007;14:1-10. doi: 10. 1007/s00534-006-1150-0.

[39] Nishino T, Hamano T, Mitsunaga Y, Shirato I, Shirato M, Tagata T, et al. Clinical evaluation of the Tokyo Guidelines 2013 for severity assessment of acute cholangitis. J Hepatobiliary Pancreat Sci 2014;21:841-849. doi: 10.1002/jhbp.189.

[40] Lee JG. Diagnosis and management of acute cholangitis. Nat Rev Gastroenterol Hepatol 2009;6:533-541. doi: 10.1038/nrgastro.2009.126.

[41] Gossard AA, Angulo P, Lindor KD. Secondary sclerosing cholangitis: a comparison to primary sclerosing cholangitis. Am J Gastroenterol 2005;100: 1330-1333. doi: 10.1111/j.1572-0241.2005.41526.x.

[42] Lutz H, Trautwein C, Tischendorf JW. Primary sclerosing cholangitis: diagnosis and treatment. Dtsch Arztebl Int 2013;110:867-874. doi: 10.3238/ arztebl.2013.0867.

[43] Abarbanel DN, Seki SM, Davies Y, Marlen N, Benavides JA, Cox K, et al. Immunomodulatory effect of vancomycin on Treg in pediatric inflammatory bowel disease and primary sclerosing cholangitis. J Clin Immunol 2013;33: 397-406. doi: 10.1007/s10875-012-9801-1.

[44] Sun Z, Zhu Y, Zhu B, Xu G, Zhang N. Controversy and progress for treatment of acute cholangitis after Tokyo Guidelines (TG13). Biosci Trends 2016;10:22-26. doi: 10.5582/bst.2016.01033.

[45] Lee NK, Kim S, Lee JW, Kim CW, Kim GH, Kang DH, et al. Discrimination of suppurative cholangitis from nonsuppurative cholangitis with computed tomography (CT). Eur J Radiol 2009;69:528-535. doi: 10.1016/j.ejrad. 2007.11.031.

[46] Tharian B, George NE, Tham TC. What is the current role of endoscopy in primary sclerosing cholangitis? World J Gastrointest Endosc 2015;7: 920-927. doi: 10.4253/wjge.v7.i10.920.

[47] Håkansson K, Ekberg O, Håkansson HO, Leander P. MR characteristics of acute cholangitis. Acta Radiol 2002;43:175-179. doi: 10.1034/j.16000455.2002.430215.x.

[48] Njei B, McCarty TR, Varadarajulu S, Navaneethan U. Systematic review with meta-analysis: endoscopic retrograde cholangiopancreatography-based modalities for the diagnosis of cholangiocarcinoma in primary sclerosing cholangitis. Aliment Pharmacol Ther 2016;44:1139-1151. doi: 10.1111/ apt.13817.

[49] Jain M, Agarwal A. MRCP findings in recurrent pyogenic cholangitis. Eur ] Radiol 2008;66:79-83. doi: 10.1016/j.ejrad.2007.05.005.

[50] Park MS, Yu JS, Kim KW, Kim MJ, Chung JP, Yoon SW, et al. Recurrent pyogenic cholangitis: comparison between MR cholangiography and direct cholangiography. Radiology 2001;220:677-682. doi: 10.1148/radiol. 2202001252.

[51] Tohda G, Ohtani M, Dochin M. Efficacy and safety of emergency endoscopic retrograde cholangiopancreatography for acute cholangitis in the elderly. World J Gastroenterol 2016;22:8382-8388. doi: 10.3748/wjg.v22.i37. 8382.

[52] Will U, Thieme A, Fueldner F, Gerlach R, Wanzar I, Meyer F. Treatment of biliary obstruction in selected patients by endoscopic ultrasonography (EUS)-guided transluminal biliary drainage. Endoscopy 2007;39:292-295. doi: 10.1055/s-2007-966215.

[53] Kogure H, Tsujino T, Yamamoto K, Mizuno S, Yashima Y, Yagioka H, et al. Fever-based antibiotic therapy for acute cholangitis following successful endoscopic biliary drainage. J Gastroenterol 2011;46:1411-1417. doi: 10.1007/s00535-011-0451-5.

[54] Navaneethan U, Gutierrez NG, Jegadeesan R, Venkatesh PG, Butt M, Sanaka MR, et al. Delay in performing ERCP and adverse events increase the 30-day readmission risk in patients with acute cholangitis. Gastrointest Endosc 2013;78:81-90. doi: 10.1016/j.gie.2013.02.003.

[55] Patel H, Gaduputi V, Chelimilla H, Makker J, Hashmi H, Irigela M, et al. Acute cholangitis: does the timing of ERCP alter outcomes? J Pancreas 2016;17: 504-509.
[56] Inamdar S, Sejpal DV, Ullah M, Trindade AJ. Weekend vs. Weekday admissions for cholangitis requiring an ERCP: comparison of outcomes in a national cohort. Am J Gastroenterol 2016;111:405-410. doi: 10.1038/ ajg.2015.425.

[57] ASGE Standards of Practice Committee, Anderson MA, Fisher L, Jain R, Evans JA, Appalaneni V, et al. Complications of ERCP. Gastrointest EndosC 2012;75:467-473. doi: 10.1016/j.gie.2011.07.010.

[58] Ishigaki T, Sasaki T, Serikawa M, Kobayashi K, Kamigaki M, Minami T, et al. Evaluation of antibiotic use to prevent post-endoscopic retrograde cholangiopancreatography pancreatitis and cholangitis. Hepatogastroenterology 2015;62:417-424.

[59] Navaneethan U, Jegadeesan R, Nayak S, Lourdusamy V, Sanaka MR, Vargo $\mathrm{J}$, et al. ERCP-related adverse events in patients with primary sclerosing cholangitis. Gastrointest Endosc 2015;81:410-419. doi: 10.1016/j.gie. 2014.06.030.

[60] Bangarulingam SY, Gossard AA, Petersen BT, Ott B], Lindor KD. Complications of endoscopic retrograde cholangiopancreatography in primary sclerosing cholangitis. Am J Gastroenterol 2009;104:855-860. doi: 10.1038/ ajg.2008.161.

[61] Ertuğrul I, Yüksel I, Parlak E, Ciçek B, Ataseven H, Başar O, et al. Risk factors for endoscopic retrograde cholangiopancreatography-related cholangitis: a prospective study. Turk J Gastroenterol 2009;20:116-121.

[62] Kwan KEL, Shelat VG, Tan CH. Recurrent pyogenic cholangitis: a review of imaging findings and clinical management. Abdom Radiol (NY) 2017;42: 46-56. doi: 10.1007/s00261-016-0953-y.

[63] Kovač JD, Weber MA. Primary biliary cirrhosis and primary sclerosing cholangitis: an update on MR imaging findings with recent developments. J Gastrointestin Liver Dis 2016;25:517-524. doi: 10.15403/jgld.2014. 1121.254.vac.

[64] Lunder AK, Hov JR, Borthne A, Gleditsch J, Johannesen G, Tveit K, et al. Prevalence of sclerosing cholangitis detected by magnetic resonance cholangiography in patients with long-term inflammatory bowel disease. Gastroenterology 2016;151:660-669.e4. doi: 10.1053/j.gastro.2016.06.021.

[65] Azizi L, Raynal M, Cazejust J, Ruiz A, Menu Y, Arrivé L. MR Imaging of sclerosing cholangitis. Clin Res Hepatol Gastroenterol 2012;36:130-138. doi: 10.1016/j.clinre.2011.11.011.

[66] Oikarinen H, Pääkkö E, Suramo I, Päivänsalo M, Tervonen O, Lehtola J, et al. Imaging and estimation of the prognostic features of primary sclerosing cholangitis by ultrasonography and MR cholangiography. Acta Radiol 2001;42:403-408. doi: 10.1080/028418501127346891.

[67] Nakai Y, Isayama H, Yamamoto N, Matsubara S, Kogure H, Mizuno S, et al. Indications for endoscopic ultrasonography (EUS)-guided biliary intervention: Does EUS always come after failed endoscopic retrograde cholangiopancreatography? Dig Endosc 2017;29:218-225. doi: 10.1111/den. 12752.

[68] Sgouros SN, Bergele C. Endoscopic ultrasonography versus other diagnostic modalities in the diagnosis of choledocholithiasis. Dig Dis Sci 2006;51: 2280-2286. doi: 10.1007/s10620-006-9218-.x.

[69] Ustundag $Y$, Eloubeidi M. The utility of duodenal endosonography examination in the diagnostic work-up of primary sclerosing cholangitis. Endoscopy 2013;45:227. doi: 10.1055/s-0032-1326012.

[70] Jeon TJ, Cho JH, Kim YS, Song SY, Park JY. Diagnostic value of endoscopic ultrasonography in symptomatic patients with high and intermediate probabilities of common bile duct stones and a negative computed tomography scan. Gut Liver 2017;11:290-297. doi: 10.5009/gnl16052.

[71] Gornals JB, Consiglieri CF, Bergamino MA. Double pigtail for preventing ascending cholangitis after endoscopic ultrasonography-guided choledochoduodenostomy with lumen-apposing metal stent. Dig Endosc 2016; 28:100. doi: $10.1111 /$ den.12548.

[72] Weismüller TJ, Lankisch TO. Medical and endoscopic therapy of primary sclerosing cholangitis. Best Pract Res Clin Gastroenterol 2011;25: 741-752. doi: 10.1016/j.bpg.2011.10.003.

[73] Itoi T, Sofuni A, Itokawa F, Tsuchiya T, Kurihara T, Ishii K, et al. Endoscopic ultrasonography-guided biliary drainage. J Hepatobiliary Pancreat Sci 2010; 17:611-616. doi: 10.1007/s00534-009-0196-1.

[74] Itoi T, Itokawa F, Kurihara T. Endoscopic ultrasonography-guided gallbladder drainage: actual technical presentations and review of the literature (with videos). J Hepatobiliary Pancreat Sci 2011;18:282-286. doi: 10. 1007/s00534-010-0310-4.

[75] Fujita N, Noda Y, Kobayashi G, Ito K, Horaguchi J, Takasawa O, et al. Endosonography-guided biliary drainage. Dig Endosc 2008;20:55-60. doi: $10.1111 /$ j.1443-1661.2008.00782.x.

[76] Bories E, Pesenti C, Caillol F, Lopes C, Giovannini M. Transgastric endoscopic ultrasonography-guided biliary drainage: results of a pilot study. Endoscopy 2007;39:287-291. doi: 10.1055/s-2007-966212.

[77] Alper E, Unsal B, Buyrac Z, Baydar B, Akca S, Arslan F, et al. Role of radial endosonography in the diagnosis of acute cholangitis. Dig Dis Sci 2011;56: 2191-2196. doi: 10.1007/s10620-010-1552-3.

[78] Naitoh I, Nakazawa T, Hayashi K, Miyabe K, Shimizu S, Kondo H, et al. Comparison of intraductal ultrasonography findings between primary 
sclerosing cholangitis and IgG4-related sclerosing cholangitis. J Gastroenterol Hepatol 2015;30:1104-1109. doi: 10.1111/jgh.12894.

[79] Naitoh I, Nakazawa T, Ohara H, Ando T, Hayashi K, Tanaka H, et al. Endoscopic transpapillary intraductal ultrasonography and biopsy in the diagnosis of IgG4-related sclerosing cholangitis. J Gastroenterol 2009;44: 1147-1155. doi: 10.1007/s00535-009-0108-9.

[80] Kobori I, Suda T, Nakamoto A, Saito H, Okawa O, Sudo R, et al. Two cases of immunoglobulin G4-related sclerosing cholangitis in which transabdominal ultrasonography was useful in diagnosis and follow-up observation. J Med Ultrason 2016;43:271-277. doi: 10.1007/s10396-015-0676-7.

[81] Kubota K, Kato S, Uchiyama T, Watanabe S, Nozaki Y, Fujita K, et al. Discrimination between sclerosing cholangitis-associated autoimmune pancreatitis and primary sclerosing cholangitis, cancer using intraductal ultrasonography. Dig Endosc 2011;23:10-16. doi: 10.1111/j.1443-1661. 2010.01039.x.

[82] Kikuchi Y, Tsuyuguchi T, Saisho H. Evaluation of normal bile duct and cholangitis by intraductal ultrasonography. Abdom Imaging 2008;33:452-456. doi: 10.1007/s00261-007-9279-0.

[83] Daly CA, Padley SP. Sonographic prediction of a normal or abnormal ERCP in suspected AIDS related sclerosing cholangitis. Clin Radiol 1996;51: 618-621. doi: 10.1016/S0009-9260(96)80054-7.

[84] Gomi H, Solomkin JS, Takada T, Strasberg SM, Pitt HA, Yoshida M, et al. TG13 antimicrobial therapy for acute cholangitis and cholecystitis. J Hepatobiliary Pancreat Sci 2013;20:60-70. doi: 10.1007/s00534-0120572-0.

[85] Weber A, Huber W, Kamereck K, Winkle P, Voland P, Weidenbach H, et al. In vitro activity of moxifloxacin and piperacillin/sulbactam against pathogens of acute cholangitis. World J Gastroenterol 2008;14:3174-3178. doi: 10. 3748 /wjg. 14.3174

[86] Shenoy SM, Shenoy S, Gopal S, Tantry BV, Baliga S, Jain A. Clinicomicrobiological analysis of patients with cholangitis. Indian J Med Microbiol 2014; 32:157-160. doi: 10.4103/0255-0857.129802.

[87] Salvador VB, Lozada MC, Consunji RJ. Microbiology and antibiotic susceptibility of organisms in bile cultures from patients with and without cholangitis at an Asian academic medical center. Surg Infect (Larchmt) 2011;12: 105-111. doi: 10.1089/sur.2010.005.

[88] Kiesslich R, Will D, Hahn M, Nafe B, Genitsariotis R, Mäurer M, et al. Ceftriaxone versus Levofloxacin for antibiotic therapy in patients with acute cholangitis. Z Gastroenterol 2003;41:5-10. doi: 10.1055/s-200336676.

[89] Voigtländer T, Leuchs E, Vonberg RP, Solbach P, Manns MP, Suerbaum S, et al. Microbiological analysis of bile and its impact in critically ill patients with secondary sclerosing cholangitis. J Infect 2015;70:483-490. doi: 10. 1016/j.jinf.2015.01.013.

[90] Reuken PA, Torres D, Baier M, Löffler B, Lübbert C, Lippmann N, et al. Risk factors for multi-drug resistant pathogens and failure of empiric first-line therapy in acute cholangitis. PLoS One 2017;12:e0169900. doi: 10.1371/ journal.pone.0169900.

[91] van Lent AU, Bartelsman JF, Tytgat GN, Speelman P, Prins JM. Duration of antibiotic therapy for cholangitis after successful endoscopic drainage of the biliary tract. Gastrointest Endosc 2002;55:518-522. doi: 10.1067/mge. 2002.122334.

[92] Dellinger RP, Levy MM, Rhodes A, Annane D, Gerlach H, Opal SM, et al. Surviving Sepsis Campaign: international guidelines for management of severe sepsis and septic shock, 2012. Intensive Care Med 2013;39: 165-228. doi: 10.1007/s00134-012-2769-8.

[93] Park TY, Choi JS, Song TJ, Do JH, Choi SH, Oh HC. Early oral antibiotic switch compared with conventional intravenous antibiotic therapy for acute cholangitis with bacteremia. Dig Dis Sci 2014;59:2790-2796. doi: 10.1007/ s10620-014-3233-0

[94] Schneider J, De Waha P, Hapfelmeier A, Feihl S, Römmler F, Schlag C, et al. Risk factors for increased antimicrobial resistance: a retrospective analysis of 309 acute cholangitis episodes. J Antimicrob Chemother 2014;69: 519-525. doi: 10.1093/jac/dkt373.

[95] Elfaki DA, Lindor KD. Antibiotics for the treatment of primary sclerosing cholangitis. Am J Ther 2011;18:261-265. doi: 10.1097/MJT.0b013e318 $1 \mathrm{~b} 7 \mathrm{~b} 8 \mathrm{c} 0$.

[96] Ali AH, Carey EJ, Lindor KD. The microbiome and primary sclerosing cholangitis. Semin Liver Dis 2016;36:340-348. doi: 10.1055/s-00361594007.

[97] Tabibian JH, Gossard A, El-Youssef M, Eaton JE, Petz J, Jorgensen R, et al. Prospective clinical trial of rifaximin therapy for patients with primary sclerosing cholangitis. Am J Ther 2017;24:e56-e63. doi: 10.1097/MJT. 0000000000000102

[98] Rahimpour S, Nasiri-Toosi M, Khalili H, Ebrahimi-Daryani N, Nouri-Taromlou MK, Azizi Z. A triple blinded, randomized, placebo-controlled clinical trial to evaluate the efficacy and safety of oral vancomycin in primary sclerosing cholangitis: a pilot study. J Gastrointestin Liver Dis 2016;25:457-464. doi: 10.15403/jgld.2014.1121.254.rah.
[99] Färkkilä $M$, Karvonen $A L$, Nurmi $H$, Nuutinen $H$, Taavitsainen $M$, Pikkarainen $P$, et al. Metronidazole and ursodeoxycholic acid for primary sclerosing cholangitis: a randomized placebo-controlled trial. Hepatology 2004;40: 1379-1386. doi: 10.1002/hep.20457.

[100] Davies YK, Cox KM, Abdullah BA, Safta A, Terry AB, Cox KL. Long-term treatment of primary sclerosing cholangitis in children with oral vancomycin: an immunomodulating antibiotic. J Pediatr Gastroenterol Nutr 2008; 47:61-67. doi: 10.1097/MPG.0b013e31816fee95.

[101] Tabibian JH, Weeding E, Jorgensen RA, Petz JL, Keach JC, Talwalkar JA, et al. Randomised clinical trial: vancomycin or metronidazole in patients with primary sclerosing cholangitis - a pilot study. Aliment Pharmacol Ther 2013;37:604-612. doi: 10.1111/apt.12232.

[102] Ray S, Sanyal S, Das K, Ghosh R, Das S, Khamrui S, et al. Outcome of surgery for recurrent pyogenic cholangitis: a single center experience. HPB (Oxford) 2016;18:821-826. doi: 10.1016/j.hpb.2016.06.001.

[103] Lee KF, Chong CN, Ng D, Cheung YS, Ng W, Wong J, et al. Outcome of surgical treatment for recurrent pyogenic cholangitis: a single-centre study. HPB (Oxford) 2009;11:75-80. doi: 10.1111/j.1477-2574.2008. 00018.x.

[104] Ahrendt SA. Surgical approaches to strictures in primary sclerosing cholangitis. J Gastrointest Surg 2008;12:423-425. doi: 10.1007/s11605-0070342-5.

[105] Bing-lu L, Chao-ji Z, Wei L, Tao H, Xie-qun X. Treatment of acute cholangitis with hepatolithiasis. Zhongguo Yi Xue Ke Xue Yuan Xue Bao 2011;33: 88-91. doi: 10.3881/j.issn.1000-503X.2011.01.019.

[106] Ignjatović II, Matić SV, Dugalić VD, Knežević DM, Micev MT, Marko D Bogdanović, et al. A case of autoimmune cholangitis misdiagnosed for cholangiocarcinoma: how to avoid unnecessary surgical intervention? Srp Arh Celok Lek 2015;143:337-340. doi: 10.2298/SARH1506337I.

[107] Lytras D, Kalaitzakis E, Webster G], Imber C], Amin Z, Rodriguez-Justo M, et al. Cholangiocarcinoma or IgG4-associated cholangitis: how feasible it is to avoid unnecessary surgical interventions? Ann Surg 2012;256: 1059-1067. doi: 10.1097/SLA.0b013e3182533a0a.

[108] Obusez EC, Lian L, Shao Z, Navaneethan U, O'Shea R, Kiran RP, et al. Impact of ileal pouch-anal anastomosis on the surgical outcome of orthotopic liver transplantation for primary sclerosing cholangitis. J Crohns Colitis 2013;7:230-238. doi: 10.1016/j.crohns.2012.06.001.

[109] Co M, Pang SY, Wong KY, Ip WK, Yuen WK. Surgical management of recurrent pyogenic cholangitis: 10 years of experience in a tertiary referral centre in Hong Kong. HPB (Oxford) 2014;16:776-780. doi: 10.1111/hpb. 12185.

[110] Al-Sukhni W, Gallinger S, Pratzer A, Wei A, Ho CS, Kortan P, et al. Recurrent pyogenic cholangitis with hepatolithiasis-the role of surgical therapy in North America. J Gastrointest Surg 2008;12:496-503. doi: 10.1007/ s11605-007-0398-2.

[111] Anselmi M, Salgado J, Arancibia A, Alliu C. Acute cholangitis caused by choledocholithiasis: traditional surgery or endoscopic biliary drainage. Rev Med Chil 2001;129:757-762.

[112] Yamamoto T, Hirohashi K, Kubo S, Tsukamoto T, Uenishi T, Shuto T, et al. Surgery for segmental primary sclerosing cholangitis. Hepatogastroenterology 2004;51:668-671.

[113] Isogai M, Yamaguchi A, Harada T, Kaneoka Y, Suzuki M. Cholangitis score: a scoring system to predict severe cholangitis in gallstone pancreatitis. J Hepatobiliary Pancreat Surg 2002;9:98-104. doi: 10.1007/s0053402 00010.

[114] Kim H, Kong T, Chung SP, Hong JH, Lee JW, Joo Y, et al. Usefulness of the delta neutrophil index as a promising prognostic marker of acute cholangitis in emergency departments. Shock 2017;47:303-312. doi: 10.1097/SHK. 0000000000000722.

[115] Tsuyuguchi T, Sugiyama H, Sakai Y, Nishikawa T, Yokosuka O, Mayumi T, et al. Prognostic factors of acute cholangitis in cases managed using the Tokyo Guidelines. J Hepatobiliary Pancreat Sci 2012;19:557-565. doi: 10. 1007/s00534-012-0538-2

[116] Qin YS, Li QY, Yang FC, Zheng SS. Risk factors and incidence of acute pyogenic cholangitis. Hepatobiliary Pancreat Dis Int 2012;11:650-654. doi: 10.1016/S1499-3872(12)60240-9.

[117] Schwed AC, Boggs MM, Pham XD, Watanabe DM, Bermudez MC, Kaji AH, et al. Association of admission laboratory values and the timing of endoscopic retrograde cholangiopancreatography with clinical outcomes in acute cholangitis. JAMA Surg 2016;151:1039-1045. doi: 10.1001/jamasurg.2016.2329.

[118] Boberg KM, Lind GE. Primary sclerosing cholangitis and malignancy. Best Pract Res Clin Gastroenterol 2011;25:753-764. doi: 10.1016/j.bpg.2011. 10.002 .

[119] Milkiewicz P, Wunsch E. Primary sclerosing cholangitis. Recent Results Cancer Res 2011;185:117-133. doi: 10.1007/978-3-642-03503-6_7.

[120] Ponsioen CY, Vrouenraets SM, Prawirodirdjo W, Rajaram R, Rauws EA, Mulder $\mathrm{CJ}$, et al. Natural history of primary sclerosing cholangitis and prognostic value of cholangiography in a Dutch population. Gut 2002;51: 562-566. doi: 10.1136/gut.51.4.562. 
[121] Tischendorf J], Hecker H, Krüger M, Manns MP, Meier PN. Characterization, outcome, and prognosis in 273 patients with primary sclerosing cholangitis: A single center study. Am J Gastroenterol 2007;102:107-114. doi: 10. 1111/j.1572-0241.2006.00872.x.

[122] Kim WR, Therneau TM, Wiesner RH, Poterucha JJ, Benson JT, Malinchoc M, et al. A revised natural history model for primary sclerosing cholangitis. Mayo Clin Proc 2000;75:688-694. doi: 10.4065/75.7.688.

[123] Ngu JH, Gearry RB, Wright AJ, Stedman CA. Inflammatory bowel disease is associated with poor outcomes of patients with primary sclerosing cholangitis. Clin Gastroenterol Hepatol 2011;9:1092-1097. doi: 10.1016/j.cgh. 2011.08.027.
[124] Kulaksiz H, Heuberger D, Engler $S$, Stiehl A. Poor outcome in progressive sclerosing cholangitis after septic shock. Endoscopy 2008;40:214-218. doi: $10.1055 / \mathrm{s}-2007-967024$.

[125] de Vries EM, Wang J, Leeflang MM, Boonstra K, Weersma RK, Beuers UH, et al. Alkaline phosphatase at diagnosis of primary sclerosing cholangitis and 1 year later: evaluation of prognostic value. Liver Int 2016;36: 1867-1875. doi: 10.1111/liv.13110.

[126] Liu W, Chen W, He X, Qu Q, Hong T, Li B. Poor response of initial steroid therapy for IgG4-related sclerosing cholangitis with multiple organs affected. Medicine (Baltimore) 2017;96:e6400. doi: 10.1097/MD. 0000000000006400 . 